\title{
FREMANEZUMAG (FREMANEZUMAB DAN MAGNESIUM) SEBAGAI INOVASI DALAM PENCEGAHAN SERANGAN MIGRAIN
}

\author{
Putri Windiana Rahman, Safira Qalbissilmi
}

\begin{abstract}
Migraine is a disease that is felt for life, often recurs and hinders the sufferer's activity. The pathogenesis of migraine is speculated to be in the trigeminal system with neurotransmitter activity such as CGRP, glutamate, serotonin and nitric oxide, cerebral artery vasodilation and neurogenic inflammation. The management of migraine with triptan consumption resulted in unexpected side effects between the use of the drug and the incidence of cerebrovascular ischemia, coronary heart disease and severe hypertension. Currently, a new and recognized treatment for migraine has been found. The medications associated with CGRP and magnesium compounds offer considerable benefits over existing drugs
\end{abstract}

Keywords: Migraine, migraine treatment innovation, calcitonin gene-related peptide (CGRP), magnesium

\begin{abstract}
Abstrak
Migrain adalah penyakit yang dirasakan seumur hidup, sering berulang dan menghambat aktivitas penderitanya. Patogenesis migrain dispekulasikan berada pada sistem trigeminal dengan aktivitas neurotransmitter seperti CGRP, glutamat, serotonin dan nitrit oksida, vasodilatasi arteri serebri serta inflamasi neurogenic. Tata laksana migrain dengan konsumsi triptan didapatkan efek samping yang tak terduga antara penggunaan obat tersebut dengan kejadian iskemik serebrovaskular, jantung coroner dan hipertensi berat. Saat ini, telah ditemukan tata laksana terbaru dan sudah diakui untuk penyakit migrain. Pengobatan yang berhubungan dengan CGRP dan senyawa magnesium menawarkan manfaat yang cukup besar dibandingkan obat-obatan yang sudah ada.
\end{abstract}

Kata Kunci: Migrain, inovasi pengobatan migrain, calcitonin gene- related peptide (CGRP), magnesium

\section{PENDAHULUAN}

Migrain adalah suatu masalah klinis dengan karakteristik nyeri kepala primer, berulang dengan manifestasi serangan selama 4-72 jam dan disertai gejala penyerta berupa mual, fotofobia, serta fonofobia. Penyakit ini dikatakan sebagai masalah seumur hidup yang mulai dirasakan saat anak-anak namun lebih sering terjadi saat usia 20-30 tahun kemudian intensitas rasa sakitnya relatif berkurang saat dewasa. Data WHO (2011) menyebutkan bahwa jenis nyeri kepala primer terbanyak ke-2 adalah migrain. Lebih dari $10 \%$ penduduk dunia berusia 1865 tahun yang menderita nyeri kepala dilaporkan menderita migrain. Sementara itu, di Amerika, terdapat 28 juta orang yang mengalami migrain dan disebutkan bahwa di dalam ruangan yang berisi 100 orang, sekiranya terdapat 13 orang yang mengalami penyakit ini. Kemudian di Indonesia, pada tahun 2008 telah dilakukan penelitian multisenter di lima rumah sakit besar oleh Sjahrir yang menunjukkan prevalensi migrain tanpa aura sebanyak $10 \%$ dan migrain dengan aura sebanyak $1,8 \%$, wanita tercatat tiga kali lebih banyak menderita migrain dibanding pria.

\section{HASIL DAN PEMBAHASAN}

Dua sindrom klinis migrain yang telah teridentifikasi menurut International Headache Society yaitu migrain dengan aura dan migrain tanpa aura.

1. Migrain dengan aura ditandai dengan serangan yang terjadi setidaknya 
sebanyak dua kali dan memenuhi kriteria :

- Minimal satu gejala defisit neurologi fokal atau gangguan fungsi saraf yang reversible yaitu visual, sensori, motorik, bahasa, batang otak dan retinal

- Minimal tiga dari enam karakteristik, diantaranya :

- Lama waktu terjadinya aura $\geq 5$ menit

- Dua atau lebih terjadinya aura secara berurutan

○ Gejala aura setiap individu berlangsung selama 5-60 menit.

- Minimal gejala aura adalah unilateral

- Minimal gejala aura positif

- Aura disertai atau diikuti sakit kepala dalam 60 menit.

2. Migrain tanpa aura ditandai setidaknya lima serangan dengan karakteristik:

- Sakit kepala berlangsung selama 4-72 jam (belum diobati atau pengobatan tidak berhasil)

- Memenuhiduadariempatkriteria:

○ Unilateral

○ Berdenyut

- Intensitas nyeri sedang hingga berat

- Diperburuk dengan atau menghambat aktivitas fisik

- Selama sakit kepala, mengalami mual dan atau muntah serta fotofobia dan fonofobia.

Terdapat beberapa hal yang mendasari patofisiologi migrain, yang pertama adalah genetik atau hereditas. Terjadinya mutasi pada kromosom 19 yang berkaitan dengan aktivitas gen CACNA1A kanal kalsium berpintu listrik atau dikenal sebagai Familial Hemiplegic Migrain (FHM-1), mutasi gen tersebut berhubungan erat dalam regulasi pengeluaran transmitter, kemampuan sel glia dalam melakukan reuptake glutamate dari sinaps saraf regulasi potensial aksi saraf. Dalam patofisiologi migrain, peningkatan aktivitas glutamate menyebabkan reseptor NMDA teraktivasi terus menerus, yang pada gilirannya dapat memperkuat transmisi rasa sakit, alodinia dan sensitisasi sentral.

Adapun neurobiology menjelaskan mengenai dasar trigeminovaskular yang berkaitan dengan terjadinya sakit kepala pada migrain. Saraf trigeminal ini bercabang menjadi tiga divisi, yang pertama adalah divisi oftalmika (V1) membentuk plexus saraf yang tidak diselubungi myelin mempersarafi pembuluh darah otak besar, vena besar dan dura mater, serta di fossa posterior. Divisi yang kedua (V2) menuju ke bagian bawah menuju maxillary, dan mandibula (V3) merupakan divisi yang ketiga (6). Nosiseptif ini berinervasi di struktur intrakranial meliputi mata, dura mater, sinus kranialis atau sinus venosus dan venavena yang mensuplai sinus-sinus tersebut) dan sirkulus Willisi, mengandung calcitonin gene- related peptide (CGRP), glutamate, pituitary adenylate cyclaseactivating polypeptide-38 (PACAP-38), dan nitrit oxide yang kemudian akan dirilis apabila saraf trigeminal terstimulasi secara mekanikal, eletrikal, maupun kimiawi seperti molekul proinflamasi atau infeksi sehingga menyebabkan pembuluh darah cranial vasodilatasi dan sel mast degranulasi, kemudian keduanya akan mengaktifkan nosiseptor yang berkontribusi pada sakit kepala migrain. Aktivitas neurepeptida ini juga diproyeksikan ke beberapa area kortikal termasuk korteks somatosensori dan visual, hal ini menjelaskan mengapa cahaya memperburuk keluhan sakit kepala pada migrain.

Secara khusus, data pertama yang dipresentasikan mengenai keberadaan 
CGRP pada sistem trigeminovaskular adalah tahun 1984 pada pertemuan Regulatory Peptide dan selanjutnya dijelaskan pada beberapa publikasi hingga saat ini. Salah satu penelitian menyatakan bahwa di ganglion trigeminal terdapat sebagian CGRP ( $C$-fibers) dan sebagian lainnya adalah CGRP receptor elements (A $\delta$-fibers). Setelah stimulasi atau depolarisasi saraf, CGRP akan dirilis dari vesikel penyimpanannya melalui eksisitosis calcium-dependent dan kemudian akan berikatan dengan reseptor CGRP di sel mast sehingga akan menyebabkan inflamasi neurogenik, reseptor CGRP di sel otot polos arteri serebral yang menyebabkan vasodilatasi arteri dan terletak di terminal saraf trigeminal yang akan mensensitisasi rasa nyeri.

Ketika terjadi sensitisasi berulang pada nosiseptif sentral dan terjadi gangguan modulasi nyeri pada neuron ini dapat mengakibatkan gejala migrain menjadi persisten, menjadikannya kronik, dimana CGRP dipastikan akan menetap saat fase interictal penyakit. Hal ini berkaitan pada studi MRI fungsional yang menunjukkan peningkatan konektivitas matriks jaringan nosiseptif ketika serangan meingkat. Selain itu, sensitisasi laten juga telah ditunjukan pada penelitian hewan setelah paparan opiod atau triptan yang persisten dan dikaitkan dengan peningkatan ekspresi CGRP serta oksida nitrit sintase dalam neuron trigeminal yang bertahan lama setelah pemberian obat tersebut dihentikan keadaan ini dihentikan dengan cara pemberian inhibitor nitrat oksida sintase dan antibody monoclonal antiCGRP dan didapatkan hasil yang potensial dari senyawa tersebut sebagai terapi pada pasien yang mengonsumsi obat sakit kepala berlebihan. Oleh karena itu, efek samping penggunaan triptan yang berlebihan perlu disampaikan kepada pasien dengan serangan migrain, setidaknya untuk mengkonsumsi triptan kurang dari 10 hari per bulan.

US Food and Drug Administration (FDA) mengumumkan mengenai profil keamanan dari triptan, didapatkan bahwa terdapat efek samping yang tak terduga antara penggunaan triptan dan kejadian iskemik serebrovaskular, jantung coroner dan hipertensi berat. Oleh karena itu perlu diperhatikan bahwa triptan kontraindikasi untuk pasien-pasien dengan penyakit iskemik serebrovaskular, jantung coroner dan hipertensi berat.

Seperti yang telah diuraikan oleh beberapa pakar mengenai peran besar CGRP pada sistem trigeminal dan perannya pada patofisiologi migrain, telah ditemukan inovasi terapi yang dapat berinteraksi dengan sistem trigeminal untuk meredakan gejala dari serangan migrain. Antibodi monoklonal selektif adalah strategi alternatif yang dapat memblokir transmisi CGRP pada pasien migrain dengan cara berikatan dengan molekul CGRP ataupun reseptornya. Penelitian ini telah sangat berhasil untuk mengurangi frekuensi serangan migrain. Antibodi terhadap CGRP dan reseptornya dilaporkan efektif mengurangi hari-hari serangan migrain pada pasien yang mengalami migrain episodik (< 15 hari/ bulan) dan migrain kronik (>15 hari/bulan). Golongan obat spesifik untuk terapi migrain ini yaitu antibodi monoklonal spesifik CGRP yang telah diakui oleh The U.S Food and Drug Administration (FDA), salah satu obat dari golongan ini yang paling efektif mengurangi rata-rata hari terjadinya serangan migrain pada pasien adalah fremanezumab. 
Fremanezumab merupakan hasil dari kloning immunoglobulin $\mathrm{G}$ (IgG) yang sangat banyak jumlahnya di sirkulasi darah dan dirancang agar memiliki potensi yang kecil untuk beriteraksi dengan obat lain (FDA 2018) karena memiliki afinitas tinggi untuk berikatan dengan CGRP dan bekerja sangat selektif sebagai inhibitor reseptor CGRP, serta memiliki waktu paruh yang lebih lama yakni sekitar 20-30 hari yang memungkinkan pasien untuk minum obat lebih jarang sehingga golongan obat tersebut cocok digunakan sebagai pengobatan profilaksis migrain. Pada fase III trial klinik pada pasien dengan migrain episodik selama lebih dari 12 bulan yang diberikan kepada 875 partisipan dengan placebo injeksi s.c setiap bulan , $225 \mathrm{mg}$ fremanezumab injeksi s.c. atau single dose $675 \mathrm{mg}$ fremanezumab s.c. di minggu pertama diikuti oleh injeksi placebo s.c setiap bulan, didapatkan hasil 47,7\% partisipan mengalami $50 \%$ perbaikan serangan migrain per hari pada grup yang diinjeksi setiap bulan dan $44,4 \%$ perbaikan serangan migrain per hari pada grup yang diinjeksi setiap empat bulan. Dari hasil yang telah didapatkan dapat dikonklusikan bahwa terdapat reduksi serangan migrain yang signifikan pada pasien migrain episodic.

Sementara pada uji klinik fase III fremanezumab pada migrain kronik dengan 1130 partisipan diberikan placebo, $675 \mathrm{mg}$ fremanezumab setiap tiga bulan atau 675225-225 mg setiap bulan, didapatkan hasil reduksi sebanyak 38\% dari partisipan yang diberikan fremanezumab setiap tiga bulan, $41 \%$ pada kelompok yang diberikan setiap bulan, dan $18 \%$ pada kelompok yang diberi placebo. Adapun dosis yang direkomendasikan menurut FDA untuk profilaksis migrain yaitu $225 \mathrm{mg}$ s.c setiap bulan atau $675 \mathrm{mg}$ setiap tiga bulan.
Efek samping dari fremanezumab terhadap sistem serebrovaskular dan kardiovaskular tidak ditemukan. Namun, kerugian yang dapat ditemukan dikarenakan obat ini tidak aktif secara oral dan harus diberikan secara parenteral dengan konsekuensi reaksi akan muncul di tempat injeksi berupa hipersensitifitas atau eritema paling sering dilaporkan. Untuk aspek efektivitas, sebagaimana yang telah dipresentasikan di 24th Annual International Meeting of the International Society for Pharmacoeconomics and Outcomes Research 2019 didapatkan bahwa fremanezumab termasuk efektif biaya dilihat dari keberhasilan pengobatan yang menghasilkan pengurangan hari serangan migrain, rata-rata 28 hari dan kemudian pengurangan 146 hari dalam 10 tahun estimasi biaya sebesar \$US6900/ tahun dibandingkan placebo dengan biaya tambahan sebesar \$US3642 setiap pasien. Oleh karena itu, penggunaan fremanezumab perlu dipertimbangkan sebagai pengobatan profilaksis migrain.

Selain peran CGRP dalam pathogenesis migrain, terdapat spekulasi bahwa, saat sakit kepala berlangsung, neuron trigeminal pada penderita migrain mengeksresi magnesium dalam jumlah yang berlebihan sehingga didapatkan hipomagnesium sementara pada serum penderita. Migrain juga berasosiasi dengan rendahnya kadar magnesium pada cairan serebrospinal dan secara in vivo $\mathrm{P}$ nuclear magnetic resonance spectroscopy (MRS) didemonstrasikan bahwa kadar magnesium rendah pada otak selama serangan dan interiktal pada pasien migrain.

Defisiensi magnesium mempengaruhi pengeluaran neurotransmitter, agregasi platelet vasokonstriksi, stimulan substansi $\mathrm{P}$ yang akan mengaktivasi serabut saraf sensori nyeri yang berhubungan dengan 
patofisiologi migrain. Oleh karena itu, magnesium memungkinkan untuk berperan dalam menangkal proses ini. Magnesium berhubungan erat dalam mekanisme ikatan glutamate dan reseptor NMDA dengan cara menutup reseptor NMDA sehingga ion kalsium tidak dapat masuk dan berikatan dengannya. Suatu penelitian menyebutkan bahwa reseptor NMDA dapat menginisiasi menyebarkan depresi kortikal, namun proses ini dapat diblokir oleh magnesium dengan cara mencegah penyebaran glutamatergik yang menyebabkan reseptor NMDA tidak teraktivasi.

Studi lain mengenai peran magnesium yaitu pada sirkulasi CGRP yang menurun pada kelompok 12 pasien wanita yang mengalami fenomena Raynaud dan tidak terjadi pada kelompok kontrol. Magnesium juga dapat memblokir reseptor serotonin sehingga serotonin (5-hydroxytryptamine [5-HT]) tidak teraktivasi yang kemudian menghambat vasokonstriksi pada pembuluh darah serebri. Penelitian pada pasien migrain juga telah dilakukan, pemberian $600 \mathrm{mg}$ trimagnesium disitrat yang dilarutkan dalam air setiap pagi, mendapatkan hasil yang signifikan yakni frekuensi serangan migrain menurun 41,6\% pada kelompok ini dan $15,8 \%$ pada kelompok placebo. Selain itu, dalam rangka evaluasi klinis, telah dilakukan Visual Evoked Potentials (VEPs) untuk mengetahui mekanisme neurogenic dan brain single-photon emission computerized tomography (SPECT) untuk melihat mekanisme vaskular yang terjadi. Pemberian magnesium oral dengan dosis $600 \mathrm{mg}$ menurunkan frekuensi serangan migrain, dimana amplitudo P1 pada VEP rendah pada kelompok pasien yang diberi perlakuan dibandingkan dengan kelompok pasien yang diberi placebo. Studi SPECT menunjukkan peningkatan yang signifikan pada aliran darah kortikal ke daerah inferolateral frontal, inferolateral temporal dan regio insular setelah pemberian magnesium, sementara tidak terjadi perubahan aliran darah pada kelompok placebo.

Magnesium telah direkomendasikan oleh United States Headache Consortium (USHC) sebagai elemen mikro yang berfungsi untuk mencegah serangan migrain. Senyawa ini merupakan salah satu lini kedua untuk pengobatan preventif migrain yang relatif aman karena efek samping yang dilaporkan jarang dan ringan. Selain itu, FDA menyebutkan bahwa senyawa magnesium adalah satu- satunya senyawa preventif migrain yang termasuk dalam kategori kehamilan tertinggi yang berarti aman dikonsumsi oleh wanita hamil.

Adapun dosis yang direkomendasikan adalah tablet magnesium oxide 400-500 mg per hari atau secara intervena dengan dosis 1-2 g magnesium sulfat, namun dosis untuk wanita hamil yang diberikan magnesium sulfat dosis tinggi secara intravena selama 5-7 hari perlu diwaspadai akan terjadinya penipisan tulang pada fetus. Sementara efek samping yang dilaporkan adalah diare terjadi pada pemberian dosis yang tinggi dan iritasi saluran cerna.

\section{KESIMPULAN DAN SARAN}

\section{Kesimpulan}

Dengan lamanya waktu tiap serangan dan frekuensi sakit kepala pada migrain, dibutuhkan pengobatan preventif yang efektif, efisien dan aman digunakan untuk berbagai kalangan penderita migrain. Berdasarkan studi kepustakaan serta penelitian yang mendukung tulisan ini, telah ditemukan manfaat FREMANEZUMAG (Fremanezumab dan Magnesium) dengan cara menghambat 
aktivitas neurotransmitter seperti CGRP, glutamat, serotonin dan nitrit oksida yang menstimulasi neuron trigeminal dan menghambat vasodilatasi arteri serebri sehingga terjadi depresi kortikal dan mencegah terjadinya inflamasi neurogenik pada sistem trigeminal. Maka, melalui inovasi ini, diharapkan frekuensi serangan migrain pada kelompok penderita penyakit tersebut menurun sehingga aktivitas penderita tidak terganggu.

\section{Saran}

Perlu dilakukan penelitian lebih lanjut mengenai interaksi obat antara fremanezumab dan magnesium, serta diuji penggunaan keduanya di Indonesia berdasarkan keterkaitan genetik dan gaya hidup masyarakat.

\section{DAFTAR PUSTAKA}

1. M. Kurniawan Isti SR. Acuan Panduan Praktik Klinis Neurologi. Jakarta: Perhimpunan Dokter Spesialis Saraf Indonesia; 2014.

2. Michael Teixido MD. Migraine - more than a Headache. Hopkins Medicines; 2014.

3. Sjahrir H. Nyeri Kepala. Perhimpunan Dokter Spesialis Saraf Indonesia; 2004.

4. Steiner TJ, Lars B. The International Classification of Headache Disorders 3rd Edition (ICHD-3) Abbreviated pocket version for reference by professional users only Title. International Headache Society; 2018.

5. Ferrari M, Klever R, Terwindt G, C A, van den MA. Migraine pathophysiology: lessons from mouse models and human genetics. Lancet Neurol. 2015;14(65-80).

6. Burstein, R ; Noseda R. Pain. Migraine patophysiology Anat trigeminovascular Pathw Assoc Neurol symptoms, cortical spreading Depress sensitization, Modul pain. 2013;S4453.

7. Dodick DW. Migraine. Lancet. 2018;391(10127):1315-30.

8. Linde LEM. New drugs in migraine treatment and prophylaxis: telcagepant and topiramate. Lancet. 2010;376(9741):645-55.

9. Schwedt $\mathrm{T}$, Chiang C, Chong C, Dodick D. Functional MRI of migraine. Lancet Neurol. 2015;14:8191.

10. De Felice M, Ossipov M, Wang R. Triptan-induced enhancement of neuronal nitric oxide synthase in trigeminal ganglion dural afferents underlies increased responsiveness to potential migraine triggers. Brain. 2010;133:2475-88.

11. Kopruszinski C, Xie J, Eyde N. Prevention of stress- or nitric oxide donor-induced medication overuse headache by a calcitonin gene-related peptide antibody in rodents. Cephalalgia. 2017;37:560-70.

12. Diener H, Dodick D, Goadsby, Lipton R, Olesen J, Silberstein S. Chronic migraine - classification, characteristics and treatment. Nat Rev Neurol. 2012;8:162-71.

13. Edvinsson L. Role of CGRP. Handb Exp Pharmacol. 2019;

14. Lambru G, Andreou AP, Guglielmetti M, Martelletti P. Emerging drugs for migraine treatment: an update. Expert Opinion on Emerging Drugs. Expert Opin Emerg Drugs. 2018; 
15. Raffaelli B, Neeb L, Reuter U. Monoclonal antibodies for the prevention of migraine. Expert Opinion on Biological Therapy. 2019;

16. Fremanezumab cost effective for migraine prevention in the US. PharmacoEcon Outcomes News. 2019;

17. Marta R, Irena B-B, Beata yluk, Przemys ${ }^{3}$ aw N, Dariusz C. The Role Of Magnesium In Migraine Pathogenesis. Potential Use of Magnesium Compounds in Prevention and Treatment of Migraine Headache. 2012;345-56.

18. Christina S-E, Alexander M. Expert Review. 2008;

19. Pringsheim T, Davenport JW, Becker WJ. Prophylaxis of migraine headache. CMAJ. 2010;182(7):E269-76.

20. Tepper D, Cleveland M. No Title. Am Migrain Fond. 2013; 